\title{
Spiritual intermediation in Islamic microfinance: evidence from Indonesia
}

\author{
Besse Wediawati ${ }^{1,2, *}$, Rike Setiawati ${ }^{1,2}$ \\ ${ }^{1}$ Doctoral Program Management, Padjadjaran University, Bandung, Indonesia \& \\ ${ }^{2}$ Department of Economics, Faculty of Economics and Business, University of Jambi, Indonesia \\ *Corresponding author: widya_anwary@yahoo.com
}

\section{ABSTRACT}

Islamic microfinance is the integration of the two forces that are growing rapidly, namely Islamic finance and microfinance. Therefore, not only has the dual mission as conventional microfinance (financial and social intermediation), Islamic microfinance also has a spiritual mission (spiritual intermediation) as a manifestation of Islamic principles which is based and a real differentiator compared to MFIs.

This study is the first empirical study to explore and establish the concept of spiritual intermediation of Islamic microfinance (IMFI) towards the concept of triple mission of MFI (i.e. financial, social and spiritual intermediation). The study used a qualitative approach with qualitative interviews and focus group discussions to 32 administrators, managers and field staff of 12 Baitul Maal wattamwil (BMT) in the city of Jambi and Kendari.

The result shows that there is a spiritual intermediary conducted by BMT in the form of spiritual practice, spiritual education and spiritual training. Spiritual practice is done in two forms of activities, 1) the daily behavior of the individual/staff in accordance with Islamic principles as exemplary forms and then into the corporate culture, and 2) the behavior of the organization in accordance with Islamic principles (Sharia compliance). Spiritual education and spiritual training have been programmed by BMT, although spiritual education is still done on a limited scale, incidental, and adapted to the conditions and needs of BMT. Spiritual training, however, has not been done at all. This is due to the lack funding, expertise and network. Therefore, a planned effort and synergy needs to be done by IMFI and all stakeholders, especially the Syariah economic community (MES) to strengthen this spiritual mission, so that the mission as a whole held together with financial and social mission. This can ultimately improve the financial literacy of sharia in Indonesia and improve public access to IMFI.

Keywords - Islamic microfinance, spiritual intermediation, spiritual practice, spiritual education, spiritual Training

\section{INTRODUCTION}

Islamic microfinance (IMFI) has become one of the important financial instrument in the Islamic world to alleviate poverty by providing microfinance services to the poor and even to the poorest $(1,2,3)$. This is possible for Islamic microfinance because it combines two of the fastest-growing sector, namely microfinance and Islamic finance. Microfinance provides financial access for the poor while Islamic finance providing Islamic moral values that care about the lives of the poor ${ }^{(4)}$

Islamic microfinance uses a different approach than conventional microfinance (MFI), which provides interest-based transactions so as to drag the clients into debt, while IMFI provides asset-based transactions by embracing the principles as taught by the Qur'an and the Hadith such as: 1) the principle of partnership (ta'awun):, 2) the principle of expediency (maslahah):, $3)$ : the principle of justice (Adl and ridho), 4) the principle of balance (tawazun): and 5): the principle of universality (rahmatan lil'alamin). IMFI prohibit the following principles: 1) Usury (riba); 2): the transaction that is uncertain and speculative (maisir); 3 ): transaction whose object is not clear (gharar), 4): transaction whose object is prohibited (haram), 5): transactions that cause injustice to the other party (dzalim) $), 6)$ : the practice of hoarding (ikhtikar) ${ }^{(5,6)}$

These principles prevent structural destruction of micro finance institutions due to the emphasis on factors of ethical, moral and social to promote equality and justice for the prosperity of the community ${ }^{(7)}$. Many studies have proven that IMFI have positive impacts in terms of 
poverty reduction, increasing household income (8), children's education, and business development ${ }^{(9)}$, an increase in sales, business expenses, net income, household expenses, also an increase in the volume of products ${ }^{(10)}$ and creating job opportunities ${ }^{(11)}$. However, some empirical studies have shown that with all that advantages, IMFI has not shown an impressive performance both in terms of outreach and financial sustainability ${ }^{(12,13)}$. CGAP survey in 2007 showed that in Bangladesh - a country with a range of MFI in the world with nearly eight million borrowers - the outreach of IMFI was only $1 \%$ or approximately 100,000 clients, while in Syria and Indonesia, respectively, only by three percent and two percent of the total micro credit outstanding in $2006^{(4)}$. There are two things that cause this: 1) internal side: IMFI is not fully able to practice Islamic principles by accommodating all Islamic financial instruments. IMFI only offer one or two Islamic financial products. 70 percent of the products offered are trading scheme, namely murabaha and Good muajjal, while cooperation schemes such as profit loss sharing mudharaba or musyaraka tend to be avoided because it is considered as high risk $^{(14)}$. Additionally, IMFI often charge a higher fee for the borrower due to economies of scale problems $(6), 2)$ the External side, the low-level of Muslim understanding about Islamic finance, also low social piety of Muslim society, can be an obstacle to IMFI.

The survey results from OJK (Indonesian Financial Services Authority) in 2013 shows that the Islamic literacy rate of Indonesian people are still low, while social piety level of Islamic countries (OIC) is at number 139 out of 208 countries surveyed, including European and American countries. Indonesia, a country with a majority of Muslim population, only ranks at $140{ }^{(15)}$. Thus, it gave rise to various negative stigma in society that IMFIs are no difference with MFIs ${ }^{(16)}$

The manifestation of low-level of Islamic financial literacy and social piety can be seen from the preferences of the Muslim community who prefer MFIs based on economic factors (low interest rate, small collateral, and the size of the loan) and the non-economic factors (quality of service, ease, speed, closeness, the methods and profiles of loan officers), than relying on religious factor (17). In relation, several studies $(18,19,20,10,21)$ highlights that IMFIs as a result of the integration of Islamic finance in microfinance, not only has two functions: social and financial intermediation, which is known as a dual mission or double bottom line ${ }^{(22,23)}$, but it also has a spiritual function ${ }^{(24)}$. This function is useful for fostering people based on sharia principles and practices (tarbiyah), deeply understood and practiced correctly (kaffah) by all IMFI's stakeholders. IMFI does not only in accordance with the Shari'a in all products, processes and activities, but also must be considered as such by their clients ${ }^{(25)}$

\section{Table 1: Summary of the conceptual research on the importance of spiritual development in IMFI}

Empirical studies that discuss religion or faith in MFI is still very limited ${ }^{15}$. Similarly, empirical studies that discuss spiritual intermediation in the MFI/IMFI has never been done. It is caused by two things: 1) Muslims schollar discusses spirituality more as a ritual or religious-based activities, 2) most of the literatures use languages other than English, such as Arabic, Indonesia, Malaysia or Persian ${ }^{14}$. This study was conducted to fill this gap, with the purpose to explore all spiritual activities undertaken by IMFIs and then build a spiritual intermediation concept based on previous studies. A Spiritual Intermediation term used in this research, in order it can be universally used by various microfinancebased religious/faith, does not only apply to Islam but also to other religions such as Christianity, Judaism, Hinduism or Buddhism. In this study, the term spiritual is more oriented toward the Islamic religion in accordance with the object of this study.

\section{METHOD}

This study used a qualitative approach and an exploratory research in accordance with the purpose of exploring and establishing the concept of spiritual intermediation. The object of this study is all IMFIs shaped Baitul Maal wattamwil in the city of Jambi (Sumatera Island) and Kendari (Sulawesi Island), totaling to eight units and four units, respectively. Selection of these two cities is based on the condition of their BMT which is experiencing growth phase. Interviews were conducted with the BMTs 36 administrators, managers and field staff as informants. Data were collected through qualitative interview techniques and Focus Group Discussion. The study was conducted in May to July, 2016

\section{RESULTS}

Based on the results of qualitative interviews and focus group discussions, BMT performs various activities related to spiritual intermediation. To see the intensity of implementation, these activities are classified into the following criteria: 1) not programmed; 2) programmed; 
3) not implemented; 4) implemented; 5) not monitored and evaluated; 6) monitored and evaluated.

\section{Table 2. Various Activities of spiritual intermediation} of BMT

Based on the results presented in the table, it can be explained as follows:

\section{a. Spiritual Practice}

The practice of sharia is seen in two dimensions, individual behavior and organizational behavior:

- Individual behavior is the behavior of all employees in accordance with the Sharia principles. This behavior is exemplary forms of BMT employees to clients or the public. This activity is carried out in two forms, namely: 1) speak good words and well mannered, such as reading basmalah (in the name of Allah) when starting any activity (e.g. closing contract with the customer, disbursement of funds, at the start of a meeting), and also say greetings to each other (Assalamualaikum) when meeting between employees and customers, 2) Behave in accordance with the demands of Sharia such as wearing a head covering (hijab) for female employees, no smoking, reading the Qur'an at leisure time, praying five times, as well as empathy and care to the poor ( $t a^{\prime} a w u n$ ). Concern for the poor is generally carried out by BMT through social funds reserved from the BMT net profit each year. The social fund also comes from alms and donation (zakat, sadaqah and infaq) derived from management and members. Exemplary sharia by almost all BMT is an activity that is programmed, implemented, monitored and evaluated internally by BMT. Although evaluation is not written, it has become a joint convention that must be obeyed. Most exemplary sharia into the corporate culture. Some BMT, like BMT Kossuma and BMT Al-Islah in Jambi standardize it into a Standard Operation Procedure or staff rules.

- Organizational behavior is the entire operational activity of BMT in accordance with Islamic principles (Sharia compliance). This dimensional views of the four indicators is presented in Table 2, point a.2. Four indicators are generally programmed, implemented, monitored and evaluated by BMT. However, monitoring and evaluation are conducted internally by BMT. Monitoring and external evaluation have not been done due to the absence of external agencies that contribute to it. In Jambi, Gakopsyah does not operate optimally, while in Kendari Gakopsyah yet exist.

\section{b. Spiritual Education}

Spiritual education is carried out by BMT with full consciousness as an Islamic financial institution which has the obligation of being not only as a financial institution, but also as a propaganda institution through spiritual education to the community. BMT spread knowledge through the activities presented in Table.2.

1) Explaining the principles and practice of sharia to the members at each annual meeting by presenting the sharia supervisory board. The level of member attendance at this event is quite high, about 60 to 90 percent. However, the time allotted for this activity is still a little bit, which is an average of 15-30 minutes. These activities programmed and carried out by BMT each year, but its effectiveness to improve the sharia knowledge of the members present is not monitored and evaluated.

2) Explains in detail about the contract and how to calculate the margin / profit sharing to each customer at the time of closing a contract. This activity is programmed and always executed, but its effectiveness in improving the sharia knowledge of clients who receive an explanation is not monitored and evaluated

3) Internal meeting (halaqah) is done to maintain and strengthen the faith and spiritual fervor of the administrators / managers. A philosophy that is believed by the managers of BMT is working as part of the worship of God, therefore they struggle (jihad) to reduce poverty in order to achieve the welfare of the faithful. Therefore, this activity is a means to strengthen the relationship and keep their faith to continue to be on the road, preaching. These activities are generally programmed, implemented, monitored and evaluated internally by BMT. Some BMT, like BMT Al-Ishlah, BMT Kossuma, BMT Bina Insan Sejahtera in Jambi city make these activities as a part of the performance appraisal.

4) Generally, recitals to members are programmed by BMT as a way to strengthen the relationship to the member. It is also intended to improve the knowledge and understanding of the members on matters related to worship. However, all BMT cannot execute it. Two things that caused them are: BMT limitation in terms of funds and human resources, as well as incompatibility issues 
schedule for members who generally are microentrepreneurs.

5) Socialization activities carried out by all BMT to the public and the government. Generally, these activities are programmed, but still carried out on a limited scale, e.g. dissemination to the public through Islamic meetings (Majelis taklim), schools and professional associations (teachers, social workers, community workers, etc.). Similarly, socialization to the government is still limited to the KUMKM (SME) Ministry to register legal entities such as cooperatives or submit funding proposals. Socialization to private parties such as companies or Islamic banking in general has not been done. This is due to limited funding, human resources and access to partnerships. These activities are generally not monitored and evaluated so that their effectiveness are not measurable.

\section{c. Spiritual Training}

Spiritual training is to enhance the BMT and community members in the implementation of sharia in everyday life. These activities are generally programmed by BMT, although almost all of BMT have not done so. This is due to limited funds and experts at the BMT for managing training. All administrators / managers BMT realize the importance of this activity to increase the faith of the Islamic society.

\section{DISCUSSION AND CONCLUSION}

All activities performed by IMFI to foster community through the dissemination of Islamic principles and good practices is a form of spiritual intermediation. This intermediation includes spiritual practices, spiritual education and spiritual training. Spiritual practice is done in two forms, namely exemplary and syariah compliance. These activities are programmed and carried out by BMT daily and become a company culture. Monitoring and evaluation are done internally, although it has not been done externally because there is no competent relevant institution to do this. So this has implications for the sharia performance and accountability of the BMT.

Spiritual education is still incidentally conducted in accordance with the conditions and needs of BMT. This activity is done on a small scale and independently by BMT. Although spiritual training was programmed as an important activity to improve the Islamic literacy of society, it has not been implemented at all. This is due to the limitation of resources, experts, funds and networks.
Thus, the spiritual intermediary function has not been strengthened as a necessity to be carried out by BMT. Therefore, it required a planned effort and synergy between BMT and other parties that have greater resources such as Ikatan Dai and the Indonesian Ulema Council (which have expert scholars), institution of zakat collection (BAZDA/BAZNAS) and the Islamic banking (which have other sources of funding) as well as sharia Economic community (which has network) to cooperate with BMT and strengthen this function to improve the Indonesia islamic financial literacy. This will have implications for the improvement of public access to MFIs.

Limitations of this study is the small sample, so it is necessary to do research involving a larger sample to be able to explore other spiritual activities in MFIs. Further quantitative research needs to be done to examine the influence of this spiritual intermediation towards improving access to IMFI and the influence of this spiritual intermediation together with financial and social intermediation towards IMFI performance.

\section{ACKNOWLEDGEMENT}

The author would like to thank Dr. Sulaeman Rachman Nidar of Universitas Padjadjaran, Indonesia for his valuable comment for the concept spiritual intermediation on this paper.

\section{REFERENCES}

1. Abdul Rahman AR. Islamic Microfinance: A Missing Component in Islamic Banking. Kyoto Bulletin Islam Area Stud 1-2. 2007;1(2):38-53.

2. Wilson R. Making development Assistance Sustainable through Islamic Microfinance. 2007;2(2):197-217.

3. Obaidullah M, Khan T. Islamic Microfinance Development: Challenges and Initiatives [Internet]. SSRN Electronic Journal. 2008 p. 1-98. Available from: http://www.ssrn.com/abstract=1506073

4. Karim N, Tarazi M, Reille X. Islamic Microfinance: An Emerging Market Niche. 2008;CGAP No 49(March):1-16.

5. Ahmed, H. (2002). Financing Microenterprises : An Analytical Study Of Islamic Microfinance Institutions. Islamic Economic Studies, 9(2), 2764. 
6. Obaidullah M. Introduction to Islamic Microfinance. Published by: IBF Net (P) Limited, India. 2008.

7. Alhuda CIBE (2013) Islamic Microfinance - A Hope for Poor. Available at: http://www.alhudacibe.com/imfc2013/summary.p hp on December 2013.

8. Cokro WM, Ismail AG. Sustainability of BMT financing for Developing Micro-enterprises. MPRA Paper No. 7434 Posted 28. Februari [Internet]. 2009 p. 1-31. Available from: http://mpra.ub.uni-muenchen.de/7434/

9. Rokhman, W. (2013). The Effect Of Islamic Microfinance On Poverty Alleviation: Study In Indonesia. Journal of Economics and Business, XI(2), 21-31.

10. Riwajanti NI. Exploring the Role of Islamic Microfinance Institution in Poverty Alleviation Through Microenterprises Development, A Case Study of Islamic Financial Cooperative ( BMT ) in Indonesia. Kyoto Bull Islam Area Stud. 2014;7(March):49-66.

11. Mohamed, A., \& Ahmed, D. (2015). The Challenges Facing Microfinance Institutions in Poverty Eradication : A Case Study in Mogadishu. International Journal of Humanities Social Sciences and Education, 2(2), 56-62.

12. Abdelkader, I. Ben, \& Salem, A. Ben. (2013). Islamic vs Conventional Microfinance Institutions: Performance analysis in MENA countries. International Journal of Business and Social Research (IJBSR), 3(5), 219-233.

13. Masyita, D. (2012). Sustainable Islamic Microfinance Institutions In Indonesia: An Exploration Of Demand \& Supply Factors And The Role Of Waqf.p. 1-313

14. Rammal, Hussain.G (2003) Mudaraba in Islamic Finance: Principles and Application. Business Journal For Entrepreneurs, Vol. 16, No. 4, pp.105112

15. Rehman SS, Askari H. How Islamic are Islamic Countries ? Glob Econoy J. 2010;10(2):1 - 37.

16. Antonio MS, Nugraha HF. Peran Intermediasi Sosial Perbankan Syariah: Inisiasi Pelayanan Keuangan Bagi Rakyat Miskin. J Keuang dan Perbank. 2012;16(2):238-52.

17. Masyita., Dian and Ahmed. H. Why is Growth of Islamic Microfinance Lower than its Conventional Counterparts in Indonesia? Islam Econ Stud. 2013;21(1):35-62.

18. Ascarya. The Sustainability Of Conventional And Islamic Microfinance Models In Indonesia. J Ekon dan Bisnis Islam Vol II, Nomor 2, Desember 2012. 2012;10 - 31 .

19. Waspodo AA. The Need to Educate Muslims on Islamic Financial Principles and Practices : A Step Towards Fertilizing in the Islamic World. Islamic Finance For Micro and Medium Enterprises. Islamic Research \& Training Institute, Islamic Development Bank \& Centre for Islamic Banking, Finance and Management \& Universiti Brunei Darussalam; 2008. p. 1 -16.

20. Mardhatillah A, Rulindo R. Building Capacity of Micro and Medium Enterprises through Spirituality Training. Islamic Finance For Micro And Medium Enterprises. Islamic Research \& Taining Institut IDB, Centre for Islamic Banking, Finance and Management Universiti Brunei Darussalam; 2008. p. 1 - 379.

21. Astha A, De Selva R. Religious Practice and Microcredit: Literature Review and Research Directions. Postmod Openings, Year 2, No 8. 2011;33-44.

22. Brau JC, Woller GM. Microfinance: A comprehensive review of the existing literature. $\mathrm{J}$ Entrep Financ [Internet]. 2004;9:1-27. Available from: http://www.econstor.eu/handle/10419/55971

23. Ledgerwood J. Sustainable Banking with the Poor. Microfinance Handbook. An Institutional and Financial Perspectives. The World Bank; 2000.

24. Sanrego YD, Antonio MS. The Effect Of Social Capital On Loan Repayment Behavior Of The Poor ( A Study On Group Lending Model ( GLM ) Application In Islamic Microfinance Institution ). J Indones Econ Bus. 2013;28(2):209-31.

25. Hoda N, Gupta SL. Faith-based Organizations and Microfinance: A Literature Review. Asian Soc Sci [Internet]. 2015 Apr 2 [cited 2015 Apr 19];11(9):245-54. Available from: http://www.ccsenet.org/journal/index.php/ass/artic le/view/47166

26. Hadisumarto. $\mathrm{W}$ and Ismail. A. G. (2010).Improving the effectiveness of Islamic micro-financing Learning from BMT experience. Humanomics Vol. 26 No. 1, 65-75. doi:10.1108/08288661011025002

27. Adnan, M. A., \& Ajija, S. R. (2015). The effectiveness of Baitul Maal wat Tamwil in reducing poverty: The case of Indonesian Islamic Microfinance Institution. Humanomics, 31(2), 160-182. 
Table 1: Summary of the conceptual research on the importance of spiritual development in IMFI

\begin{tabular}{|c|c|c|}
\hline Researcher / Year & Concept & Dimensions \\
\hline Waspodo (2008) & $\begin{array}{l}\text { Education for the Muslim community about the } \\
\text { principles and practices of Islamic finance is a step } \\
\text { to improve knowledge so that Muslims adhere to } \\
\text { the teachings and principles of Islam }{ }^{(19)}\end{array}$ & Religious education \\
\hline $\begin{array}{l}\text { Hadisumarto.W \& } \\
\text { Ismail.A.G (2010); } \\
\text { Adnan \& Ajija (2015) }\end{array}$ & $\begin{array}{l}\text { Spiritual development is an important instrument } \\
\text { for poverty reduction through the internalization of } \\
\text { Islamic moral values in the consciousness of a } \\
\text { Muslim businessman }\end{array}$ & Spiritual development \\
\hline Ascarya (2012) & $\begin{array}{l}\text { Ethics/religious education as well as other services } \\
\text { such as education, healthcare, empowerment, } \\
\text { financial planning and other social services are } \\
\text { needed to meet the needs of micro businesses }\end{array}$ & $\begin{array}{l}\text { Ethics/Religious } \\
\text { Education }\end{array}$ \\
\hline Riwajanti (2012) & $\begin{array}{l}\text { Religious training to be more intense in socializing } \\
\text { their financing products to wider community, to } \\
\text { better educate their customers in order to improve } \\
\text { customers' understandings on Islamic terms used in } \\
\text { financing Products }{ }^{(10)}\end{array}$ & Religious training \\
\hline $\begin{array}{l}\text { Mardhatillah \& Rulindo } \\
\text { (2008) }\end{array}$ & $\begin{array}{l}\text { Spiritual training proposes the use of Islamic } \\
\text { spirituality to increase direct people's ability in } \\
\text { leadership and human capital towards improving } \\
\text { their life performance through Emotional Spiritual } \\
\text { Quotient (ESQ) i.e. Ihsan, Iman and Islam }{ }^{(20)}\end{array}$ & Spiritual training \\
\hline Astha \& De Selva (2011) & Religious practices ${ }^{(21)}$ & Religious practice \\
\hline Sanrego (2013) & $\begin{array}{l}\text { Spiritual approach together with financial approach } \\
\text { and social approach is the empowerment of the } \\
\text { poor and ensure that they are worthy of financial } \\
\text { services and they are able to repay the loan }{ }^{(24)}\end{array}$ & Spiritual approach \\
\hline
\end{tabular}

Source: Literature survey 
Table 2. Various Activities of spiritual intermediation of BMT

\begin{tabular}{|c|c|c|c|c|c|c|c|c|}
\hline Dimensions & Definition & Indicator & 1 & 2 & 3 & 4 & 5 & 6 \\
\hline \multirow{6}{*}{$\begin{array}{l}\text { a. } \text { Spiritual } \\
\text { Practice }\end{array}$} & Individual & 1) Good-spoken and polite (tayyibah) & & $\mathrm{v}$ & & $\mathrm{v}$ & & $\mathrm{V}$ \\
\hline & $\begin{array}{l}\text { Behavior of BMT managers } \\
\text { in accordance with the } \\
\text { guidance of sharia } \\
\text { (exemplary) }\end{array}$ & $\begin{array}{l}\text { 2) Behave in accordance with the } \\
\text { guidance of the Prophet } \\
\text { Muhammad (pbuh) }\end{array}$ & & $\mathrm{v}$ & & $\mathrm{v}$ & & $\mathrm{v}$ \\
\hline & $\begin{array}{l}\text { Organizational behavior: } \\
\text { BMT operates in accordance }\end{array}$ & $\begin{array}{l}\text { 1) The supervisory board of Sharia } \\
\text { in the organizational structure }\end{array}$ & & $\mathrm{v}$ & & $\mathrm{v}$ & & $\mathrm{V}$ \\
\hline & $\begin{array}{l}\text { with Islamic principles } \\
\text { (sharia compliance) }\end{array}$ & $\begin{array}{l}\text { 2) Managers that understand well } \\
\text { the Islamic financial literacy }\end{array}$ & & $\mathrm{v}$ & & $\mathrm{v}$ & & $\mathrm{V}$ \\
\hline & & $\begin{array}{l}\text { 3) All the operational activities in } \\
\text { accordance with Islamic } \\
\text { principles }\end{array}$ & & $\mathrm{v}$ & & $\mathrm{v}$ & & V \\
\hline & & $\begin{array}{l}\text { 4) Supervision of the sharia } \\
\text { regularly }\end{array}$ & & $\mathrm{v}$ & & $\mathrm{v}$ & & $\mathrm{V}$ \\
\hline \multirow[t]{5}{*}{$\begin{array}{l}\text { b. Spiritual } \\
\text { Education }\end{array}$} & $\begin{array}{l}\text { Spread the knowledge of the } \\
\text { principles and practice of } \\
\text { sharia to improve the } \\
\text { knowledge and understanding } \\
\text { of the members and the }\end{array}$ & $\begin{array}{l}\text { Explaining the principle and } \\
\text { practice of sharia to the } \\
\text { members/clients at each annual } \\
\text { meeting by presenting the sharia } \\
\text { supervisory Board }\end{array}$ & & $\mathrm{v}$ & & $\mathrm{v}$ & V & \\
\hline & community & $\begin{array}{l}\text { Explaining in detail about the } \\
\text { contract and how to calculate the } \\
\text { margin / profit sharing to every } \\
\text { customer in every binding } \\
\text { contract }\end{array}$ & & $\mathrm{v}$ & & $\mathrm{v}$ & $\mathrm{V}$ & \\
\hline & & $\begin{array}{l}\text { Improving and maintaining a } \\
\text { spiritual spirit (ruhiyah aspects) } \\
\text { of the } \\
\text { administrators/managers/field } \\
\text { Officers through Internal meeting } \\
\text { periodically (halaqah) }\end{array}$ & & $\mathrm{v}$ & & $\mathrm{v}$ & & $\mathrm{V}$ \\
\hline & & $\begin{array}{l}\text { Improving and maintaining a } \\
\text { spiritual spirit (ruhiyah aspects) } \\
\text { of the members/clients through } \\
\text { Internal meeting periodically } \\
\text { (halaqah) }\end{array}$ & & $\mathrm{v}$ & $\mathrm{v}$ & & $\mathrm{V}$ & \\
\hline & & $\begin{array}{l}\text { Socialize the existence of BMT } \\
\text { and Islamic patterns in a variety } \\
\text { of external meetings }\end{array}$ & & $\mathrm{v}$ & & $\mathrm{v}$ & $\mathrm{V}$ & \\
\hline $\begin{array}{l}\text { c. Spiritual } \\
\text { training }\end{array}$ & $\begin{array}{l}\text { Training to improve the skills } \\
\text { of members and Community } \\
\text { associated with the practice } \\
\text { of sharia }\end{array}$ & - & & $\mathrm{v}$ & $\mathrm{v}$ & & $\mathrm{V}$ & \\
\hline
\end{tabular}

Source: Qualitative interview and FGD, 2016 